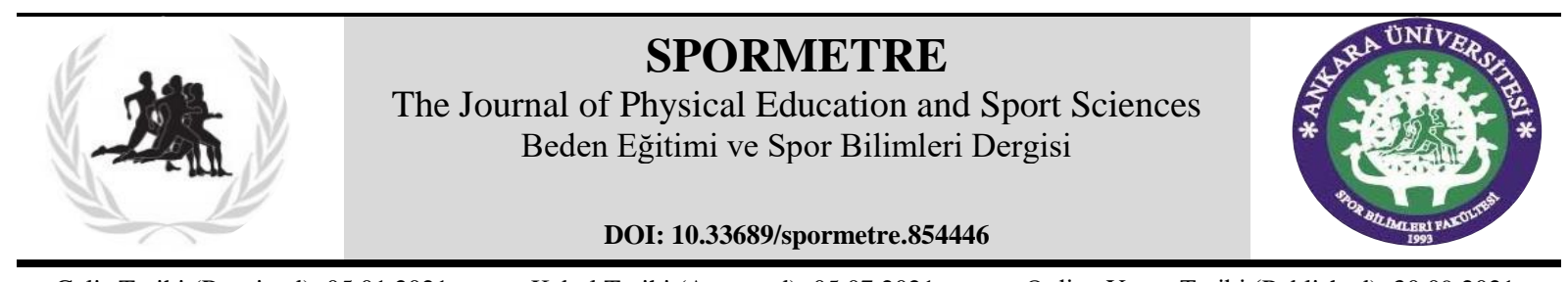

Geliş Tarihi (Received): 05.01.2021 Kabul Tarihi (Accepted): 05.07.2021

Online Yayın Tarihi (Published): 30.09.2021

\title{
ANALYSIS OF THE PERFORMANCE OF FOOTBALL TEAMS VIA THE ENTROPY-GRAY RELATIONAL ANALYSIS METHOD: TURKISH SUPER LEAGUE MODEL
}

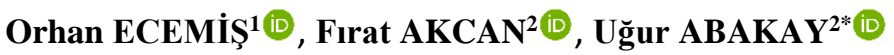 \\ ${ }^{1}$ Gaziantep Üniversitesi, Oğuzeli MYO, GAZİANTEP \\ ${ }^{2}$ Gaziantep Üniversitesi, Spor Bilimleri Fakültesi, GAZİANTEP
}

\begin{abstract}
The aim of this study was to analyze the score performances of football teams competing in the 20182019 season of the Turkish Football Federation (TFF) Super League via entropy gray relational analysis, one of the multi-criteria decision-making methods. In the study, eight criteria in relation to physical and technical qualities (total running distance, sprint running distance, running distance, getting the ball in the air, shot on target, shot pass total, crossing the ball into penalty, retrieving the ball) were taken as the standard. All matches played in the league throughout the season by engaging teams were included within the scope of this research and were evaluated on the basis of their per-match averages. Obtained data were weighted via the entropy method in order to determine the overall performance, physical performance, and technical performance of football teams. By implementing the gray relational analysis method overall, physical and technical performances of every single team was respectively analyzed. The performance ranking and actual ranking of the 2018-2019 football season were compared with each other, and obtained results were then interpreted. It was concluded that analyses via the entropy method suggested that the most significant criteria in measuring the overall performance of the teams were getting the ball in the air, shot on target, crossing the ball into penalty, and total pass; for physical performance, the criteria vital standards were getting the ball in the air and for technical performance criteria, shot on target played a major role. Based on the gray relational analysis method, it was concluded that the overall performance and the physical and technical performances of the teams failed to represent their actual rankings.
\end{abstract}

Keywords: football, performance, entropy, gray relational analysis

\section{FUTBOL TAKIM PERFORMANSLARININ ENTROPI-GRI İLISKISEL ANALIZZ YÖNTEMIYLE DEĞERLENDIRILMESİ: TÜRKIYYE SÜPER LİG ÖRNEĞİ}

Öz: Bu çalışma, 2018-2019 Sezonu Türkiye Futbol Federasyonu (TFF) Süper Liginde mücadele eden futbol takımlarının müsabaka performanslarının çok kriterli karar verme yöntemlerinden olan Entropi-Gri İlişkisel Analiz yöntemiyle değerlendirilmesi amacıyla yapılmışıtır. Çalışmada fiziksel ve teknik özelliklerinden 8 kriter (toplam koşu mesafesi, sprint koşu mesafesi, yüksek yoğunluklu koşu mesafesi, hava topu kazanma, kaleyi bulan sut, isabetli pas sayısı, ceza sahasına toplam orta, topa sahip olma) ölçü olarak alınmıştır. Sezon boyunca takımların ligde oynadıkları tüm müsabakalar çalışma kapsamına dahil edilerek maç bası ortalamaları üzerinden değerlendirilmiştir. Elde edilen veriler, futbol takımlarının genel performans, fiziksel performans ve teknik performanslarını belirlenmesi için Entropi yöntemiyle ağırlıklandırılmışıır. Gri ilişkisel analiz yöntemiyle, takımların ayrı ayrı genel, fiziksel ve teknik performansları değerlendirilmiştir. Performans sıralaması ile 20182019 yılı gerçek sıralama karşılaştırılmış ve sonuçlar yorumlanmıştır. Sonuç olarak; entropi yöntemi ile yapılan analizler göstermektedir ki, takımların genel performanslarında en önemli kriterlerin hava topu kazanma, kaleyi bulan sut, ceza sahasına toplam orta ve pas sayısı olduğu, fiziksel performans kriterleri arasında hava topu kazanmanın, teknik performans kriterlerinde de kaleye yapılan isabetli sutların oldukça önemli olduğu söylenebilir. Gri ilişkisel analiz yöntemine göre takımların genel performans, fiziksel ve teknik performanslarının gerçek sıralamaları ile örtüşmediği sonucuna ulaşılmıştır.

Anahtar Kelimeler: Futbol, performans, entropi, gri ilişkisel analiz 


\section{INTRODUCTION}

Football is among the most popular sports in the world (Günay and Yüce, 2008). The football industry has become increasingly popular over the world and still continues to be a magnet for large masses (Güngör, 2014; Karamatov et al., 2019). To attain global as well as national success in football, it is necessary to make use of scientifically grounded methods (Günay and Yüce, 2008). Along with advancements in technology, statistical data have become more frequently employed in football. Statistical data can provide objective and remarkably crucial insights for the technical staff in determining playing techniques and tactics in addition to the performance of players. Professional football clubs favor establishing statistic units in their organizations and work to enhance their chances of success by allocating significantly large budgets to run these units (Lago and Martín, 2007).

As competition in football has escalated, small details have attracted even more value, leading to the need to form cooperation among multiple disciplines. Scientific studies have shown that for attaining success in football, the possession of advanced technical and tactical skills by team players, strong team finances, large numbers of supporters and similar factors are not adequate on their own for high scoring. The way to attain success in advanced football and to maintain such success is through truly knowing and implementing the factors that can carry teams to the top (Mao et al., 2016; Marchiori and de Vecchi, 2020). Thus, the aim of this study was to identify the most effective performance factors for being successful in football using multicriteria decision-making methods.

In relevant literaturem multi-criteria decision-making (MCDM) methods are used liberally in various assessment and selection problems. Unlike statistical methods, in MCDM methods, it is not necessary to form main hypotheses for criteria or variables (Yang et al., 2020).

By emphasizing the uncertainties that exist as a natural consequence of the decision-making process, Munier (2011) pointed out current subjective dimensions that call for attention and explained the principles for adopting them.

In the decision-making process, it is essential to implement maximum objectivity to make it possible to minimize subjective perceptions from decision-makers, administrators, or analysts. The estimation of criteria weights used in the process and the expression of a preference for one action over another in certain models or certain indifference or acceptance levels should be carefully distanced from subjective judgments. The decision-making process should be planned in such a way as to eliminate any doubts regarding the transparency of the entire process and to explain the kind of actions performed on which grounds. There must be a document indicating the justification of the motives for any decision made.

With a problem that requires making a decision or a project that contains subjective values, the mechanisms that can be adapted to make approximate computations for these values are surveys, public opinion polls, and the Delphi technique (Munier, 2011).

Multi-criteria decision-making methods have been employed in many different domains, some of which are as exemplified in the table below (Akçakanat et al., 2017; Çakır and Perçin, 2013; Tunca et al., 2016). 
Table 1. Studies on Performance Assessment Measured via MCDM Method

\begin{tabular}{|c|c|c|c|c|}
\hline Author & Year & Subject & Method(s) & Criteria Weighting \\
\hline Tunca et al. & 2012 & $\begin{array}{l}\text { Performance assessment of OPEC } \\
\text { Members }\end{array}$ & MAUT & Entropy \\
\hline Perçin and Selçuk & 2013 & $\begin{array}{l}\text { Assessment of R \& D. performances of } \\
\text { the EU member states }\end{array}$ & Topsis & Entropy \\
\hline Akçakanat et al. & 2017 & $\begin{array}{l}\text { Performance assessment in Turkish } \\
\text { banking sector }\end{array}$ & WASPAS & Entropy \\
\hline Kenger et al. & 2017 & Personnel selection & Aras & Entropy \\
\hline Wang et al. & 2015 & $\begin{array}{l}\text { Assessment of social responsibility in } \\
\text { airline transport }\end{array}$ & $\begin{array}{l}\text { Gray } \\
\text { Relational } \\
\text { Analysis }\end{array}$ & Entropy \\
\hline Yildırım and Uysal & 2019 & Personnel selection in airline companies & Aras & Expert View \\
\hline
\end{tabular}

In this study, which was carried out in light of the below listed data, it was aimed to compare expected the league ranking according to team performances with the actual ranking attained at the end of season in the league and display the significance order of the selected criteria by taking into account some of the physical and technical qualities of football teams.

\section{METHOD}

Conducted to analyze score performance of the teams competing in the Turkish Football Federation (TFF) Super League, this is a study in which the multi-criteria decision-making method was utilized. In order to carry out this research, the Ethics Committee Report was obtained from the Social and Human Sciences Ethics Committee of Gaziantep University with the decision dated 23.12.2020 and numbered 4.

\section{Data Collection}

In this study, the data used belonged to the per-match average performance statistics for all the matches played by competing teams in the TFF Super League during the 2018-2019 season since pandemic measures were not yet a concern for the league at that time. Analysis took place primarily in two categories, the physical and technical dimensions. An overall performance analysis was also conducted by summing up the two factors. The performance criteria designated for this study are as below,

Table 2. Parameters Employed in the Study and Relevant Abbreviations

\begin{tabular}{lll}
\hline \multirow{4}{*}{ Physical Parameters } & \multicolumn{1}{c}{ Criteria (per-match) } & Abbreviations \\
\cline { 2 - 3 } & Total Running distance & TRD \\
\cline { 2 - 3 } Technical Parameters & Sprint Distance & SD \\
\cline { 2 - 3 } & High intensity running distance & HIRD \\
\cline { 2 - 3 } & Getting the ball in the air & GBA \\
\cline { 2 - 3 } & Shot on target & ST \\
\cline { 2 - 3 } & Total pass & CBP \\
\cline { 2 - 3 } & Crossing the ball into penalty & RB \\
\cline { 2 - 3 } & Retrieving the ball & \\
\hline
\end{tabular}

\section{Data Collection Tools}

The data in this study were utilized by obtaining a special license from a private company named Instat-Sentio. To test their reliability, these data were compared with "benefit" featured data presented on tr.whoscored.com sites that posted international statistics on football (LagoPeñas, Gómez-Ruano et al., 2017). 


\section{Data Analysis}

In the analysis of data, the Microsoft Excel program was used to weight the criteria via the entropy method. The gray relational analysis method was applied to the weighted criteria. The implementation steps are as displayed in the table.

\section{Entropy Method}

Suggested by Rudolph Clausius (1865), entropy can be defined as the criterion of irregularity and uncertainty in an existing system. Adapted into information theory by Shannon (1948), entropy is employed in physical and social sciences today. In data mining, it is one of the methods used to gauge information gain in the data set. The entropy method consists of five steps (Wang and Lee, 2009, Karami and Johansson, 2014). To normalize the decision matrix with respect to cost and benefit, it is computed via normalization $\mathrm{P}_{\mathrm{ij},}$, hence, to measure its uncertainty $d_{j}$, criteria weights are then computed.

\section{Gray Relational Analysis Method}

In daily life, the color "black" is used to indicate unknown information, the color "white" is used to indicate fully known information, and the color "gray" is used to indicate partially known and partially unknown information. Accordingly, systems having fully known information are evaluated as white, systems having fully unknown information are evaluated as black, and systems consisting of partially known and partially unknown information are evaluated as gray. In 1982, the gray system theory was suggested by Deng in his article "The Control Problems of Gray Systems," The focal point of gray system theory consists of uncertainty problems as well as poor information and small data sets that are not similar to the problems treated by statistical, fuzzy mathematic, or rough set theory (Liu et al., 2017). The gray relational analysis method is a powerful assessment model that measures with respect to relationship size the degree of similarity or difference between two sets, and this method exhibits the importance of spot set topology. Therefore, instead of local comparison via gauging the distance between two spots, a global comparison across two data sets is performed so as to ensure that model parameters are free from adopting subjective values (Chan \& Tong, 2007). In the gray relational analysis method, the designation of a factor compatibility to perform a global comparison between alternatives producing a reference series by computing a gray relational coefficient can all be achieved after detecting the gray relational degree.

\section{FINDINGS}

\section{Criteria Weighting Via Entropy Method}

The criteria weights of overall, physical, and technical performances were respectively computed via the entropy method.

Table 3. Criteria Weights of Overall Performance

\begin{tabular}{ccccccccc}
\hline \multicolumn{4}{c}{ Physical Criteria } & \multicolumn{3}{c}{ Technical Criteria } \\
\hline & TRD & SD & HIRD & GBA & ST & PS & CBP & RB $(\%)$ \\
\hline$E_{J}$ & 0.9999 & 0.9994 & 0.9995 & 0.9966 & 0.9968 & 0.9979 & 0.9975 & 0.9990 \\
\hline$d_{j}$ & 0.0001 & 0.0006 & 0.0005 & 0.0034 & 0.0032 & 0.0021 & 0.0025 & 0.0010 \\
\hline$w_{j}$ & 0.0047 & 0.0460 & 0.0405 & 0.2517 & 0.2380 & 0.1568 & 0.1850 & 0.0774 \\
\hline \multicolumn{3}{c}{$E_{j}$ Entropy value, ${ }^{d}{ }_{j}$ Uncertainty value, ${ }^{w}{ }^{*}$ Criteria Weight } & & & &
\end{tabular}

Table 3 displays the weighting of teams' overall performance criteria via the entropy method. Accordingly, the most effective criteria forming $83 \%$ of the total weight were identified as getting the ball in the air, shot on target, crossing the ball into penalty, and total pass. 
Table 4. Criteria Weights of Physical Performance

\begin{tabular}{ccccc}
\hline & TRD & SD & HIRD & GBA \\
\hline$E_{J}$ & 0.9999 & 0.9994 & 0.9995 & 0.9966 \\
\hline$d_{j}$ & 0.0001 & 0.0006 & 0.0005 & 0.0034 \\
\hline$w_{j}$ & 0.0136 & 0.1341 & 0.1181 & 0.7342 \\
\hline
\end{tabular}

Table 4 displays the criteria weights of physical/conditional performances of the teams via the entropy method. Accordingly, the most effective criterion was detected as getting the ball in the air, and, when other criteria weight values were investigated, the weights of sprint distance and high intensity running distance criteria were computed to be similar whereas the weight ratio of total running distance was measured as the lowest.

Table 5. Criteria Weights of Technical Performance

\begin{tabular}{ccccc}
\hline & ST & PS & CBP & RB (\%) \\
\hline$E_{J}$ & 0.9968 & 0.9979 & 0.9975 & 0.9990 \\
\hline$d_{j}$ & 0.0032 & 0.0021 & 0.0025 & 0.0010 \\
\hline$w_{j}$ & 0.3621 & 0.2386 & 0.2815 & 0.1178 \\
\hline
\end{tabular}

Table 5 displays the criteria weights of the technical/tactical performance of the teams via the entropy method. Accordingly, the most effective criterion was detected as shot on target while total pass and crossing the ball into penalty were computed to be similar; the retrieving the ball criterion was measured as the lowest weight.

\section{Findings with the Gray Relational Analysis Method}

The assessment of the football teams' performance procedural steps for overall, physical, and technical performance assessment are as listed in the appendix of this study.

Table 6. Overall Performance Ranking of the Teams Via Gray Relational Analysis Method

\begin{tabular}{clcccccccccc}
\hline Rankings & \multicolumn{1}{c}{ Teams } & TRD & SD & HIRD & GBA & ST & PS & CBP & RB & $\begin{array}{c}\text { Actual } \\
\text { Rankings }\end{array}$ \\
\hline 1 & Bursa S.K. & 0.0041 & 0.0460 & 0.0244 & 0.2517 & 0.0935 & 0.0706 & 0.1850 & 0.0417 & 16 \\
\hline 2 & Besiktas & 0.0021 & 0.0237 & 0.0220 & 0.1435 & 0.2181 & 0.0910 & 0.1387 & 0.0493 & 3 \\
\hline 3 & Kasimpasa & 0.0040 & 0.0423 & 0.0405 & 0.1226 & 0.1636 & 0.0618 & 0.1850 & 0.0285 & 14 \\
\hline 4 & M. Basaksehir & 0.0047 & 0.0214 & 0.0252 & 0.0839 & 0.1378 & 0.1568 & 0.1233 & 0.0774 & 2 \\
\hline 5 & Galatasaray & 0.0018 & 0.0218 & 0.0150 & 0.1367 & 0.1378 & 0.1031 & 0.1233 & 0.0774 & 1 \\
\hline 6 & Trabzonspor & 0.0024 & 0.0224 & 0.0189 & 0.1032 & 0.2380 & 0.0841 & 0.0925 & 0.0417 & 4 \\
\hline 7 & Fenerbahçe & 0.0029 & 0.0242 & 0.0211 & 0.1393 & 0.1047 & 0.0956 & 0.1387 & 0.0452 & 6 \\
\hline 8 & Caykur Rize S.K. & 0.0042 & 0.0246 & 0.0182 & 0.1794 & 0.1190 & 0.0706 & 0.0793 & 0.0339 & 11 \\
\hline 9 & Sivas S.K. & 0.0034 & 0.0345 & 0.0333 & 0.1167 & 0.1138 & 0.0710 & 0.1009 & 0.0339 & 12 \\
\hline 10 & Alanya S.K. & 0.0020 & 0.0220 & 0.0192 & 0.1304 & 0.1309 & 0.0575 & 0.1110 & 0.0301 & 9 \\
\hline 11 & Goztepe & 0.0025 & 0.0299 & 0.0185 & 0.1543 & 0.0935 & 0.0648 & 0.0925 & 0.0361 & 15 \\
\hline 12 & Konya S.K. & 0.0035 & 0.0181 & 0.0218 & 0.1649 & 0.0793 & 0.0623 & 0.0740 & 0.0285 & 8 \\
\hline 13 & Akhisar S.K. & 0.0023 & 0.0158 & 0.0141 & 0.1025 & 0.1007 & 0.0629 & 0.1009 & 0.0301 & 18 \\
\hline 14 & Erzurum BB & 0.0032 & 0.0161 & 0.0159 & 0.1018 & 0.0935 & 0.0632 & 0.0925 & 0.0339 & 17 \\
\hline 15 & Kayseri S.K. & 0.0021 & 0.0204 & 0.0144 & 0.1003 & 0.1091 & 0.0626 & 0.0740 & 0.0361 & 10 \\
\hline 16 & Ankaragücü & 0.0016 & 0.0153 & 0.0135 & 0.1304 & 0.0873 & 0.0562 & 0.0617 & 0.0301 & 13 \\
\hline 17 & Y.Malatya S.K. & 0.0021 & 0.0175 & 0.0158 & 0.1167 & 0.0873 & 0.0523 & 0.0694 & 0.0285 & 5 \\
\hline 18 & Antalya S.K. & 0.0025 & 0.0160 & 0.0160 & 0.1196 & 0.0844 & 0.0553 & 0.0617 & 0.0258 & 7 \\
\hline & & & & & & & & & \\
\hline
\end{tabular}


Table 6 shows the analyses for the criteria selected via the gray relational analysis method. It was thus determined that the overall performance ranking we obtained and the actual ranking at the end of league failed to align. The ranking attained based on teams' overall performance indicated that the first three orders belonged to Bursa S.K., Besiktas, and Kasimpasa. In the getting the ball in the air criterion, Bursa S.K. was detected to be the best in the league, and in the shot on target criterion, Trabzon S.K. was detected to be the best in the league.

Table 7. Physical Performance Ranking of the Teams Via Gray Relational Analysis Method

\begin{tabular}{clccccc}
\hline Rankings & \multicolumn{1}{c}{ Teams } & TRD & SD & HIRD & GBA & $\begin{array}{c}\text { Actual } \\
\text { Rankings }\end{array}$ \\
\hline 1 & Bursa S.K. & 0.0118 & 0.1341 & 0.0710 & 0.7342 & 16 \\
\hline 2 & Caykur Rize S.K. & 0.0121 & 0.0717 & 0.0532 & 0.5231 & 11 \\
\hline 3 & Kasimpasa & 0.0116 & 0.1233 & 0.1181 & 0.3577 & 14 \\
\hline 4 & Konya S.K. & 0.0102 & 0.0528 & 0.0636 & 0.4810 & 8 \\
\hline 5 & Goztepe & 0.0073 & 0.0873 & 0.0538 & 0.4500 & 15 \\
\hline 6 & Besiktas & 0.0060 & 0.0690 & 0.0642 & 0.4185 & 3 \\
\hline 7 & Sivas S.K. & 0.0099 & 0.1005 & 0.0971 & 0.3402 & 12 \\
\hline 8 & Fenerbahce & 0.0084 & 0.0706 & 0.0616 & 0.4063 & 6 \\
\hline 9 & Galatasaray & 0.0052 & 0.0635 & 0.0437 & 0.3986 & 1 \\
\hline 10 & Alanya S.K. & 0.0057 & 0.0643 & 0.0560 & 0.3805 & 9 \\
\hline 11 & Ankaragücü & 0.0045 & 0.0447 & 0.0394 & 0.3805 & 13 \\
\hline 12 & Antalya S.K. & 0.0072 & 0.0467 & 0.0466 & 0.3488 & 7 \\
\hline 13 & Y. Malatya S.K. & 0.0061 & 0.0509 & 0.0460 & 0.3402 & 5 \\
\hline 14 & Trabzon S.K. & 0.0069 & 0.0652 & 0.0553 & 0.3011 & 4 \\
\hline 15 & Kayseri S.K. & 0.0061 & 0.0596 & 0.0420 & 0.2927 & 10 \\
\hline 16 & Erzurum BB & 0.0095 & 0.0469 & 0.0462 & 0.2968 & 17 \\
\hline 17 & M. Basaksehir & 0.0136 & 0.0623 & 0.0734 & 0.2447 & 2 \\
\hline 18 & Akhisar S.K. & 0.0067 & 0.0460 & 0.0412 & 0.2989 & 18 \\
\hline
\end{tabular}

Table 7 shows the analyses on physical criteria via the gray relational analysis method. In that analysis, large differences were detected between obtained physical performance ranking and actual ranking obtained at the end of the league season. According to the physical data, the first three ranks belonged to Bursa S.K., Caykur Rize S.K., and Kasimpasa. Nevertheless, it was identified that the physical performance data for Akhisar S.K., having finished the league in the last place, and its end-of-league ranking failed to overlap.

Table 8. Technical Performance Ranking of the Teams Via Gray Relational Analysis Method

\begin{tabular}{|c|c|c|c|c|c|c|}
\hline Rankings & Teams & ST & PS & CBP & $\mathbf{R B}$ & $\begin{array}{c}\text { Actual } \\
\text { Rankings }\end{array}$ \\
\hline 1 & Besiktas & 0.3319 & 0.1385 & 0.2111 & 0.0750 & 3 \\
\hline 2 & M. Basaksehir & 0.2097 & 0.2386 & 0.1877 & 0.1178 & 2 \\
\hline 3 & Trabzon S.K. & 0.3621 & 0.1280 & 0.1408 & 0.0634 & 4 \\
\hline 4 & Galatasaray & 0.2097 & 0.1569 & 0.1877 & 0.1178 & 1 \\
\hline 5 & Kasimpasa & 0.2490 & 0.0940 & 0.2815 & 0.0434 & 14 \\
\hline 6 & Bursa S.K. & 0.1423 & 0.1075 & 0.2815 & 0.0634 & 16 \\
\hline 7 & Fenerbahce & 0.1593 & 0.1455 & 0.2111 & 0.0687 & 6 \\
\hline 8 & Alanya S.K. & 0.1992 & 0.0875 & 0.1689 & 0.0458 & 9 \\
\hline
\end{tabular}


Table 8. Technical Performance Ranking of the Teams Via Gray Relational Analysis Method (Cont.)

\begin{tabular}{cllllll}
\hline 9 & Sivas S.K. & 0.1732 & 0.1081 & 0.1536 & 0.0515 & 12 \\
\hline 10 & Caykur Rize S.K. & 0.1811 & 0.1075 & 0.1207 & 0.0515 & 11 \\
\hline 11 & Akhisar S.K. & 0.1532 & 0.0958 & 0.1536 & 0.0458 & 18 \\
\hline 12 & Goztepe & 0.1423 & 0.0986 & 0.1408 & 0.0550 & 15 \\
\hline 13 & Erzurum BB & 0.1423 & 0.0962 & 0.1408 & 0.0515 & 17 \\
\hline 14 & Kayseri S.K. & 0.1660 & 0.0953 & 0.1126 & 0.0550 & 10 \\
\hline 15 & Konyaspor & 0.1207 & 0.0949 & 0.1126 & 0.0434 & 8 \\
\hline 16 & Y. Malatya S.K. & 0.1328 & 0.0795 & 0.1056 & 0.0434 & 5 \\
\hline 17 & Ankaragücü & 0.1328 & 0.0856 & 0.0938 & 0.0458 & 13 \\
\hline 18 & Antalya S.K. & 0.1285 & 0.0842 & 0.0938 & 0.0393 & 7 \\
\hline
\end{tabular}

Table 8 shows analyses of technical criteria via the gray relational analysis method. In that analysis, large differences were detected between obtained technical performance ranking and actual ranking obtained at the end of the league. According to technical data first three ranks belonged to Besiktas, M. Basaksehir and Trabzon S.K. It was identified that end-of-league ranking obtained by Medipol Basaksehir and its technical performance ranking overlapped.

\section{CONCLUSION AND DISCUSSION}

In the last part of this study, the obtained results of the entropy and gray relational analysis methods applied independently with respect to selected score performances of the teams were alternately listed in order to conduct analyses.

As the overall performance criteria weighting of the teams via the entropy method were examined, it was revealed that the most effective criteria forming $83 \%$ of total weight belonged to getting the ball in the air, shot on target, crossing the ball into penalty, and total pass dimensions. It can thus be argued that technical performance parameters were more effective.

In terms of physical performance criteria weights, the most effective criterion was detected as getting the ball in the air, and other criteria weight values were computed to be identical. Accordingly, in technical performance criteria weights, the most effective criterion was detected as shot on target while total pass and crossing the ball into penalty were computed to be similar; retrieving the ball criterion was measured as the lowest weight.

As the analyses for the criteria selected via the gray relational analysis method were examined, it was determined that overall performance ranking and obtained actual ranking at the end of the league failed to overlap. Ranking attained based on teams' overall performance indicated that the first three orders belonged to Bursa S.K., Besiktas, and Kasimpasa. In getting the ball in the air, Bursa S.K. and, in the shot on target criterion, Trabzonspor was detected to be the best in the league. In that analysis, large differences were detected between the obtained physical performance ranking and actual ranking obtained at the end of the league. According to the physical data, the first three ranks belonged to Bursa S.K., Caykur Rize S.K., and Kasimpasa. Nevertheless, it was identified that the physical performance data of Akhisar S.K., which finished the league in the last place, and its end-of-league ranking failed to overlap. Large differences were detected between the technical performance ranking and actual ranking obtained at the end of the league season. According to the technical data, the first three ranks belonged to Besiktas, M. Basaksehir, and Trabzon S.K. It was identified that the end-of-league ranking obtained by Medipol Basaksehir and its technical performance ranking overlapped. 
Penas et al. (2010) in his performance analysis on the Spain Laliga teams concluded that winning teams exhibited greater technical performance than losing teams (Lago-Peñas et al., 2010). Grant et al. (1999) in an analysis of the 1998 World Cup concluded that, unlike those failing to reach the semi-final technical parameters of the teams climbing to semi-final were noticeably better.

Aslan and Akcan (2020) in their study on the effect of technical qualities and conditional qualities in football on overall success reported that technical qualities played a more effective role in success compared to conditional qualities. Jones et al. (2004) documented that in the England Premier League, successful teams retrieved greater numbers of balls than losing teams.

Mao et al. (2016) analyzed 2014-2015 seasonal matches played in China's Professional Football League and identified that successful teams had statistically higher levels of the shot on target ratio and shot percentage at the end of the season unlike losing teams. In the same vein, a largest number of studies suggested that, in football, technical qualities had a greater determining role for success than conditional qualities (Chan and Tong, 2007; Lago and Martín, 2007; Liu, Yang et al., 2017, Pappalardo and Cintia, 2018).

The findings we obtained at the end of this study were extensively supported by the relevant literature. Findings have suggested that, thanks to advanced technology and sports science in football, human limits could be exponentially outrun in advanced football whilst the possibility for unlimited development of technical and tactical skills resulted in gaining a more determinant role for technical and tactical skills to reach success in football (Chatzopoulos et al., 2006).

As detected in the conducted analyses, the divergence between the rankings obtained by the teams and the actual rankings at the end of the league brings to mind potential reasons such as referee error, players' own mistakes, and various psychological factors.

In conclusion, it can be argued that as evidenced by the analyses performed via the entropy method, technical parameters are more effective in the overall performance of the teams. The most significant criteria were, in the category of physical performance, getting the ball in the air and, in the technical performance category, shot on target. It is safe to argue that according to the gray relational analysis method, overall performance, the physical and technical performances of the teams failed to align with their actual rankings.

\section{REFERENCES}

Akçakanat, Ö., Eren H., Aksoy E., Ömürbek, V. (2017). Bankacılık sektöründe entropi ve waspas yöntemleri ile performans değerlendirmesi. Suleyman Demirel Üniversitesi İktisadi ve İdari Bilimler Fakültesi Dergisi, 22(2), 285-300.

Aslan, M. A. A., F1rat. (2020). Futbolda kondisyonel ve teknik özelliklerin basarlya olan etkisinin incelenmesi (Türkiye Süper Ligi örneği). Gaziantep Üniversitesi, Sağlık Bilimleri Enstitüsü, Beden Eğitimi ve Spor Anabilim Dalı, Yüksek Lisans Tezi, 50.

Chan, J.W., Tong, T.K. (2007). Multi-criteria material selections and end-of-life product strategy: Grey relational analysis approach. Materials-Design, 28(5), 1539-1546.

Chatzopoulos, D., Tsormbatzoudis, H., Drakou, A. (2006). Combinations of technique and games approaches: Effects on game performance and motivation. Journal of Human Movement Studies, 50(3), 157-170. 
Çakır, S., Perçin, S. (2013). AB ülkeleri’nde bütünlesik entropi ağırlık-topsis yöntemiyle ar-ge performansının ölçülmesi. Uludă Üniversitesi İktisadi ve İdari Bilimler Fakültesi Dergisi, 17(1), 77-95.

Grant, A.G., Williams, A.M., Reilly, T. (1999). Analysis of the goals scored in the 1998 World Cup. Journal of sports sciences, 17(10), 826-827.

Günay, M., Yüce, A.İ. (2008). Futbol antrenmanının bilimsel temelleri. Gazi Kitabevi, Ankara.

Güngör, A. (2014). Futbol Endüstrisinde sportif basari ile finansal performans arasindaki iliskinin analizi ve türkiye uygulamasi. Istanbul Üniversitesi Sosyal Bilimler Dergisi, 1, 16-36.

Jones, P., James, N., Mellalieu, S. (2004). Possession as a performance indicator in soccer. International Journal of Performance Analysis in Sport, 4(1), 98-102.

Karamatov, O., Dilek, S., Nematoviç, K.I., Kamaci, A. (2019). Futbol ekonomisi: Kastamonu Üniversitesi örneği. Bartın Üniversitesi İktisadi ve İdari Bilimler Fakültesi Dergisi, 10(20), 238-264.

Karami, A., Johansson, R. (2014). Short paper. Journal of Information Science and Engineering, 30, 519-534.

Lago-Peñas, C., Ruano M.A.G., Gai., Y. (2017). Styles of play in professional soccer: an approach of the Chinese Soccer Super League. International Journal of Performance Analysis in Sport, 17(6), 1-12.

Lago-Peñas, C., Ballesteros, J.L., Dellal, A., Lopez, M.G. (2010). Game-related statistics that discriminated winning, drawing and losing teams from the Spanish soccer league. Journal of Sports Science and Medicine, 9(2), 288-293.

Lago- Peñas, C., Acero, R.M. (2007). Determinants of possession of the ball in soccer. Journal of Sports Sciences, 25(9), 969-974.

Liu, S., Yingjie Y., Jeffrey, F. (2017). Grey data analysis. Springer, Singapore.

Mao, L., Peng Z., Liu H., Ruano MAG. (2016). Identifying keys to win in the Chinese professional soccer league. International Journal of Performance Analysis in Sport, 16(3), 935-947.

Marchiori, M., De Vecchi, M. (2020). Secrets of soccer: Neural network flows and game performance. ComputersElectrical Engineering, 81, 1-13.

Munier, N. (2011). A strategy for using multicriteria analysis in decision-making: a guide for simple and complex environmental projects, Springer, Singapore.

Pappalardo, L., Cintia, P. (2018). "Quantifying the relation between performance and success in soccer." Advances in Complex Systems, 21, 3-4.

Tunca, M. Z., Ömürbek, N., Cömert, H.G., Aksoy, E. (2016). Opec ülkelerinin performanslarının çok kriterli karar verme yöntemlerinden entropi ve maut ile değerlendirilmesi. Süleyman Demirel Üniversitesi Vizyoner Dergisi, $7(14), 1-12$.

Wang, T.C., Lee, H.D. (2009). Developing a fuzzy TOPSIS approach based on subjective weights and objective weights. Expert Systems with Applications, 36(5), 8980-8985.

Yang, J.J., Chuang, Y.C., Wei Lo, H., Lee, T. (2020). A two-stage MCDM model for exploring the Influential relationships of sustainable sports tourism criteria in taichung city. International Journal of Environmental Research and Public Health, 17(7), 2319-2335. 